\title{
DISINFECTANTS AND DEVICES FOR SURFACE AND AIR DISINFECTION IN DENTAL OFFICES
}

\author{
Jacek Matys, Kinga Grzech-Leśniak, Marzena Dominiak \\ Department of Oral Surgery, Wroclaw Medical University, Poland
}

\begin{abstract}
SARS-CoV-2 virus pandemic that caused COVID-19 disease has altered the entire dental community. Because of COVID-19 pandemic, almost all dental practices in Poland were closed for few weeks and later, some of the offices were treating emergency patients only. Medical market offers a variety of different disinfection products for dental offices; however, not all of them significantly eradicate the virus. The present overview of various disinfectants and disinfection devices/methods showed the most substantially beneficial for application in dental clinics. Considering the advantages and disadvantages of the devices described in this paper, the highest level of air disinfection present plasma devices, which work without any additional filters that need to be replaced. In turn, fumigators with hydrogen peroxide for spraying provide the highest bactericidal, virucidal, and fungicidal effects on surfaces in the dental office (walls, medical devices, cabinets, countertops, etc.), with minimal side effects and short time needed to re-enter the office after disinfection. It should be remembered that fumigators require hydrogen peroxide plasma or chemically stabilized hydrogen peroxide to operate with high efficiency at low solution percentage. Correct application of a disinfectant with suitable method for its application improves the effectiveness of disinfection and reduces the risk of infection of staff and patients.
\end{abstract}

KEY wORDs: coronavirus, COVID-19, disinfection, disinfectants, SARS-CoV-2.

\section{INTRODUCTION}

Maximum efficiency of disinfection and sterilization is closely related to cleaning and removing organic and inorganic matters from medical instruments and surfaces in a dental office. Chemicals used to disinfect dental tools and rooms include, among others, alcohol, formaldehyde, chlorine, hydrogen peroxide, and phenols. The use of a disinfectant should depend on its target and device used for its spreading/spraying. The correct application of disinfectant and the use of appropriate method for its application improve the effectiveness of disinfection and reduce the risk of infection of staff and patients. As documented in the scientific literature, improper dis- infection of medical offices may lead to an increase in the number of infections and diseases [1].

SARS-CoV-2 virus pandemic that caused COVID-19 disease has altered the entire dental community [2]. Because of COVID-19 pandemic, almost all dental practices in Poland were closed for few weeks and later, some of the offices were treating emergency patients only. In general, dentistry and dental business collapsed all over the world and changed the level of self-protection in dental offices. In Poland, in order to help and guide the dentists, the Polish Dental Association and the National Ministry of Health prepared a recommendation to treat only emergency cases in full personal protection equipment (PPE), such as safety glasses and face shield, face

\section{JOURNAL OF STOMATOLOGY CZASOPISMO STOMATOLOGICZNE

ADDRESS FOR CORRESPONDENCE: Jacek Matys, Department of Oral Surgery, Wroclaw Medical University, 26 Krakowska St., 50-425 Wrocław, Poland, e-mail: jacek.matys@wp.pl

ReCEIVED: 29.05.2020 • ACCEPTED: 30.06.2020 • Published: 30.08.2020 
mask N-95 or FFP3, wrist covering gloves, long-sleeved medical apron, and headgear [2]. Furthermore, many studies underlined the disinfection validity of room surfaces and air using various devices/ methods, including ventilation system, ultraviolet lamps, high-volume evacuator, automated room disinfection systems with hydrogen peroxide vapor (fumigation) [3-5].

During the COVID-19 pandemic, many companies offer different disinfection products for application in dental offices; however, not all of them significantly eradicate the virus. The present overview of various disinfectants and disinfection devices/ methods indicates which of them may be substantially beneficial for application in dental clinics.

\section{PART 1}

Overview of disinfectants that can be used in dental offices, with advantages and disadvantages described in the table below (Table 1) [6-9].

\section{PART 2}

Overview of disinfection devices that can be used in dental offices with advantages and disadvantages (Figure 1).

\section{OZONE GENERATORS}

Air ozonizer (ozonator) is a device, in which ozone is formed under the influence of electric current that has a strong disinfecting effect. Ozonators eradicate bacteria, viruses, fungi, and their spores. However, the disadvantage of air ozonizers, which are made of ceramic tiles, is that they form nitrogen oxides causing destructive and discoloring effect on plastic elements and rubber structures, e.g., gaskets. On the other hand, the advantage of using ozonation is strong decontamination of air, removal of inhalation allergens, and unpleasant odors. However, ozone generators cannot be used together with other disinfection devices, such as UV lamps. Choosing

TABLE 1. Overview of disinfectants that can be used in dental offices

\begin{tabular}{|c|c|c|}
\hline Disinfectant & Advantages & Disadvantages \\
\hline Hydrogen peroxide & $\begin{array}{l}\text { - No activation required } \\
\text { - Increases the efficiency of removing organic matters } \\
\text { - Easily removable from the surface } \\
\text { - Odorless, not irritating the skin } \\
\text { - Bactericidal, virucidal, and fungicidal properties } \\
\text { - Scientifically proven effectiveness }\end{array}$ & $\begin{array}{l}\text { - Requires stabilization (chemical or plasma) } \\
\text { - Possible reaction with surfaces covered with brass, zinc, } \\
\text { copper, and silver } \\
\text { - Irritates the eyes }\end{array}$ \\
\hline Ozone gas & $\begin{array}{l}\text { - Bactericidal, virucidal, and fungicidal properties } \\
\text { - Strong disinfecting effect at a concentration of } 13 \mu \mathrm{g} / \mathrm{dm}^{3} \\
\text { - Breaks down into oxygen }\left(\mathrm{O}_{2}\right)\end{array}$ & $\begin{array}{l}\text { - Damages plastic and rubber } \\
\text { - Bad smell } \\
\text { - Ozone irritation may cause cough, sore throat, drowsiness, } \\
\text { and headache }\end{array}$ \\
\hline Chlorine compounds & - Bactericidal, virucidal and fungicidal properties & $\begin{array}{l}\text { - Damages plastic and rubber } \\
\text { - Causes metal corrosion } \\
\text { - Unstable, its distribution accelerates light and heat } \\
\text { - Antagonistic effects with detergents and formaldehyde } \\
\text { - Irritates the skin, conjunctiva, and respiratory tract }\end{array}$ \\
\hline Peroxide acid $0.2 \%$ & $\begin{array}{l}\text { - Side products environmentally friendly (acetic acid, } \mathrm{O}_{2^{\prime}} \\
\text { and } \mathrm{H}_{2} \mathrm{O} \text { ) } \\
\text { - Can improve organic matters' removal } \\
\text { - Easy to remove from the surface } \\
\text { - Strong fungicidal effect }\end{array}$ & $\begin{array}{l}\text { - Can damage/tarnish aluminum surfaces } \\
\text { - Possibility of serious damage to the eyes and skin through } \\
\text { a contact with undiluted solution }\end{array}$ \\
\hline Ortoftalal aldehyd 0.55\% & $\begin{array}{l}\text { - Fast disinfecting effect } \\
\text { - No activation needed } \\
\text { - Slight odor } \\
\text { - Easily removable from the surface }\end{array}$ & $\begin{array}{l}\text { - Leaves stains on the skin, mucous membranes, clothes, } \\
\text { and surfaces } \\
\text { - High price } \\
\text { - Eye irritation } \\
\text { - Slow fungicidal action }\end{array}$ \\
\hline Glutar aldehyd > 2\% & $\begin{array}{l}\text { - Scientifically proven action } \\
\text { - Low price } \\
\text { - Bactericidal, virucidal, and fungicidal properties }\end{array}$ & $\begin{array}{l}\text { - Irritates the respiratory tract } \\
\text { - Sharp, irritating odor } \\
\text { - Adheres to the surface } \\
\text { - Allergic contact dermatitis }\end{array}$ \\
\hline Phenol compounds $1.5-5 \%$ & - Bactericidal and virucidal properties & $\begin{array}{l}\text { - Weak fungicidal effect } \\
\text { - Can damage porous surfaces } \\
\text { - Irritates the skin and eyes }\end{array}$ \\
\hline
\end{tabular}




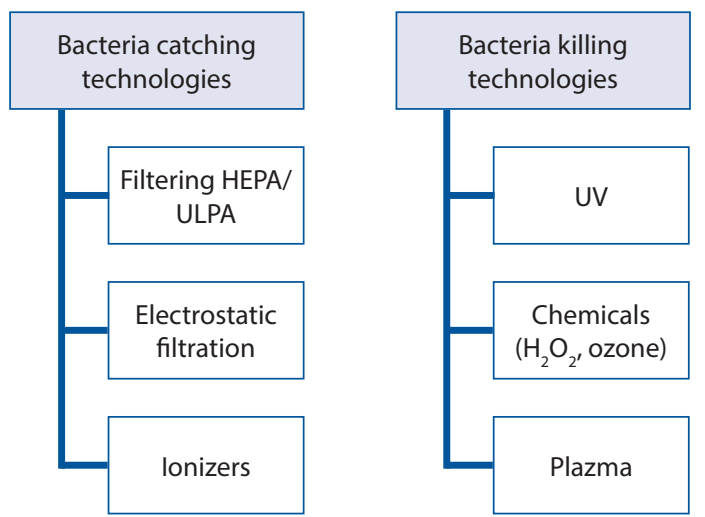

FIGURE 1. Disinfection methods

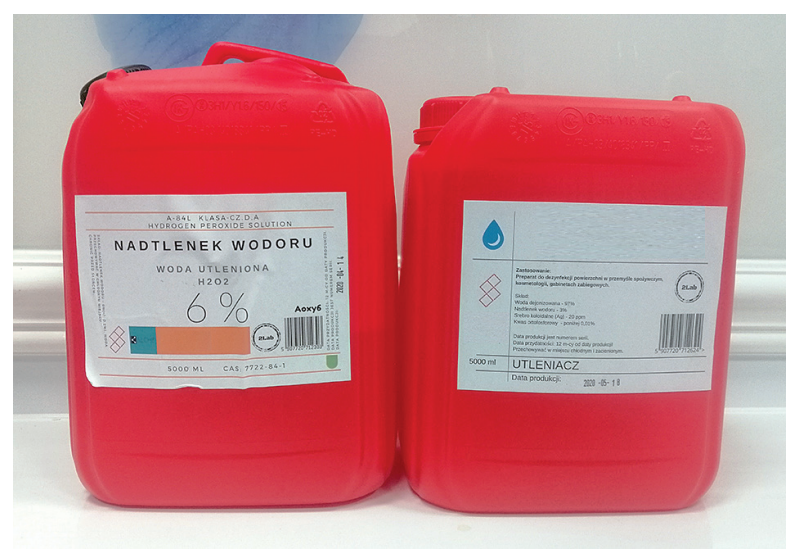

FIGURE 2. Non-stabilized and chemically stabilized hydrogen peroxide. Both products were stored in cold $15^{\circ} \mathrm{C}$ and dark room for 6 weeks. A) Non-stabilized hydrogen peroxide (distension of the container). B) Chemically stabilized hydrogen peroxide

the dose of ozone appropriate to the size of the room is particularly crucial, since disproportionate ozone saturation can oxidize the medical devices and equipment, leading to their failure. Average room disinfection using ozonizer takes about 4 to 5 hours, with waiting time after ozonation of at least 2 hours before re-entering the room. It is also recommended to ventilate the office after ozonation [10-12].

\section{SUMMARY OF ADVANTAGES AND DISADVANTAGES OF OZONE GENERATORS}

Advantages:

- strong disinfecting effect. Disadvantages:

- risk of damage to medical equipment, seals, and plastic components,

- long disinfection procedure (up to 5 hours) and waiting time for re-entering the office (about 2 hours).

\section{FOGGING EQUIPMENT}

These devices can utilize different substances for spraying, such as hydrogen peroxide, chlorine dioxide, and a mixture of peracetic acid with hydrogen peroxide.

Hydrogen peroxide generators are widely used for dental offices disinfection. They can apply hydrogen peroxide in the form of aerosol or steam. Hydrogen peroxide generators in the form of aerosol usually use a 3-7\% concentration of hydrogen peroxide with or without silver ions. They contain $\mathrm{H}_{2} \mathrm{O}_{2}$ particles with sizes ranging from 2 to $12 \mu \mathrm{m}$, which present a high bactericidal and virucidal properties $[9,13]$.

In turn, hydrogen peroxide generators in a kind of steam use hydrogen peroxide in the so-called 'dry form' (a hand put to the generator nozzle at $1 \mathrm{~m}$ should remain dry during operation). They apply various concentrations of $\mathrm{H}_{2} \mathrm{O}_{2}$, e.g., $30 \%$ hydrogen peroxide, since they can eliminate multiple pathogens, such as $M y$ cobacterium tuberculosis, Mycoplasma, Acinetobacter, Clostridium difficile, Bacillus anthracis, viruses, and prions. They have a very high bactericidal and virucidal effects $[9,13,14]$.

Fumigators can be divided depending on a construction:

1. Turbine fumigators - they have a speed of about 22,000 $\mathrm{rpm}$, which eject the aerosol with a pressure of about $80 \mathrm{~m} / \mathrm{s}$ (measured at the end of nozzle). The advantage of these devices is high quality mist and good filling of the room with aerosol. Disadvantages include high price, very loud operation $(75 \mathrm{~dB})$, and a limitation to one chemical agent indicated by the manufacturer.

2. Compressed air fumigators - air per nozzle is fed from the compressor. Advantages: an interesting alternative for dental practices that are already equipped with compressed air installations, loudness below $50 \mathrm{~dB}$, excellent fog quality, greater possibilities for regulation and control of the process (time, pressure, nozzle adjustment), no movable parts and turbines. Disadvantages: minimum compressor capacity of approximately 100 1/min and nearly 3-4 bars of pressure [15-17].

\section{SUMMARY OF ADVANTAGES AND DISADVANTAGES OF FUMIGATORS}

Advantages:

- short disinfection procedure with about $10 \mathrm{~min}$ utes on average, and short ventilation time after fumigation with about 30 minutes (time depends on the concentration of fumigation agent),

- strong decontamination effect,

- safe for medical and electronic devices (minimal increase in air humidity),

- low cost (compressed air fumigators). Disadvantages:

- quite high price (turbine fumigators), 
- low availability of stabilized hydrogen peroxide during the COVID-19 pandemic (it is essential to ask the distributors of fumigators whether they supply stabilized hydrogen peroxide),

- no medical staff can be in the room during the fumigation process.

\section{ULTRAVIOLET LAMPS}

$\mathrm{UV}-\mathrm{C}$ radiation is a result of low-pressure mercury discharges (germicidal radiators). During the operation of these devices, a UV-C electromagnetic wave, with length ranging between 250 and $270 \mathrm{~nm}$, is generated. The bactericidal mechanism of UV-C lamps is evoked by DNA damage. UV-C radiation eliminates or limits the ability of organisms to reproduce. The maximum bactericidal effectiveness for UV-C is around $265 \mathrm{~nm}$. Disinfecting lamps should be selected according to the size of a dental office, e.g., for a $15-18 \mathrm{~m}^{2}$, two $30 \mathrm{~W}$ lamps should be used. In addition to classic bactericidal lamps, UV-C flow lamps are also available on the market, in which contaminated air is sucked in by a fan and pre-filtered. Then, the air is transferred to a disinfection chamber where it is subjected to irradiation. A UV-C lamp should be turned on for 2-8 hours to achieve the appropriate bactericidal effect on surfaces $[18,19]$.

\section{SUMMARY OF ADVANTAGES AND DISADVANTAGES OF ULTRAVIOLET LAMPS}

\section{Advantages:}

- easy disinfection procedure. Disadvantages:

- no destruction of spores larger than many bacteria and viruses,

- highly resistant to UVGI,

- no effect on dust mites and allergens,

- to get a bactericidal effect, the lamp should be turned on for many hours,

- disinfecting effects on surfaces are obtained after 8 hours of continuous application,

- staying in the room while the UV-C lamp is working is forbidden.

\section{AIR FILTRATION SYSTEMS}

\section{CONVENTIONAL FILTRATION}

Ultra-low particulate air (ULPA) and high-efficiency particulate air (HEPA) filters capture particles from the air stream, but HEPA filters initially retain larger clusters of bacteria. Still, after a while, a single bacterium is released, which starts to replicate. Moreover, the small size of holes in the ULPA filters requires more pressure and energy needed to run the system. HEPA filtration is often used in combination with other technologies. By retention of the pathogens, filters create a localized biological hazard, which is why they need to be replaced regularly $[20,21]$.

Advantages:

- possibility of continuous operation, filtration of particles larger than $0.3 \mu \mathrm{m}$.

Disadvantages:

- colonization of filters is a common problem of physical filters since they capture rather than destroy bacteria and fungi. Also, filters are a good medium for the growth of bacteria and fungi because of captured dust and other organic particles,

- trapped atmospheric dust can serve as a nutrient for fungi and this process can transform the filter into a secondary source of pollution,

- HEPA filtration does not capture or kill viruses.

\section{ELECTROSTATIC FILTRATION}

This method uses an electric current to transfer a positive or negative charge to solid particles and microorganisms in the air. Subsequently, they are passed through an electrostatic filter with the opposite charge [22, 23].

Advantages:

- ability to capture smaller particles in the air and trap them in a localized filter.

Disadvantages:

- problems with filtration of larger particles (bacteria, pollen),

- the weight of larger particles combined with the airflow forces them to overcome the electric field's attraction. They stick to surfaces and devices with opposite charges, e.g., leather.

\section{IONIZERS}

While ionizers can remove various airborne contaminants, some of them remain in the room. Impurities, when attached to a negative particle, settle on the walls and floor. Over time, ionizers can cause the so-called 'black wall effect', i.e., they change the color of walls and furniture to gray. Combined particles as a result of the ionizer action can stay on the surface of ventilation ducts [24].

In a study, Grinshpun et al. [25] in indoor air tested five different ionic air purifiers, and assessed their ability to reduce aerosol exposure in closed rooms. The authors reported that "unipolar ionic air purifiers effectively reduce aerosol exposure in the breathing zone when used in confined spaces with a relatively high surface-to-volume ratio (such as car cabins, aircraft seating, bathrooms, offices, small living spaces, and animal housing)". This means that this technology should be considered for use in small enclosed areas and is not suitable for larger spaces. 


\section{FLOW ULTRAVIOLET GERMICIDAL IRRADIATION LAMPS}

Ultraviolet germicidal irradiation (UVGI) is an electromagnetic radiation that can destroy microorganisms' ability to multiply, causing photochemical changes in nucleic acids [26].

\section{PROBLEMS WITH TIME EXPOSURE IN FLOW LAMPS}

UVC irradiation of microorganisms requires longer exposure time to ensure an adequate level of disinfection. In the air channel of a modern HVAC (heating, ventilation, and air conditioning) system, the passage time through the UVC source is insufficient to obtain a significant impact. UVC flow lamps cannot provide direct deactivation, because bacteria and viruses pass through the air in groups or assemble on top of each other on a surface. This results in shading, in which the top layer of cells protects the bottom layers of cells from UV rays. Studies have shown that the effectiveness of UVGI in killing or inactivating microorganisms decreases when humidity in the room exceeds $60 \%$. Water adsorption on the virus surface can provide protection against UV-induced DNA or RNA damage [27, 28].

\section{IMPACT ON MEDICAL PERSONNEL}

The national toxicological program classifies UV-C as a possible carcinogen for humans. Excessive exposure to UV-C radiation can adversely affect the eyes, causing dermatitis and/or conjunctivitis. Chronic UV exposure can accelerate skin aging and increase the risk of skin cancer $[26,29]$.

\section{PHOTOCATALYTIC OXIDATION}

Photocatalytic oxidation (PCO) devices use UV light that irradiates reactive chemicals, such as titanium dioxide, to create free radicals that are effective in killing microorganisms. The operating power of UV light and cost of replacement make an essential contribution to the annual cost of PCO devices [30].

The main problem in PCO applications is the aging of the photocatalyst environment and the creation of unwanted by-products.

A study published in the "Journal of Building and the Environment" explored the possibilities and limitations of photocatalytic air purifiers [31]. Studies have shown that by-products formed during photocatalytic oxidation can be toxic for vital organisms [30, 31].

\section{PLASMA}

The plasma field of dielectric discharges effectively destroys viruses and fungi due to production of posi- tive and negative ions, electrons, radicals, and UV radiation. Plasma discharges consist of electrons and ions that cause significant damage to microorganisms, such as viruses, bacteria, and fungi [32]. The most effective and, at the same time, the safest plasma solutions are those, in which microorganisms are directly exposed to dielectric discharges in the plasma field, where none of the by-products of discharges (ionization, UV) escape from the device [33]. There are also solutions, in which microorganisms are exposed to by-products of these discharges. Therefore, it is necessary to verify whether they meet the safety standards for electrical medical devices (e.g., IEC 60601-1 and 60601-1-2) [32-34].

Advantages:

- strong disinfecting bactericidal, virucidal, and fungicidal proprieties,

- no filters, catalysts, and no need to add disinfectants,

- the ability to stay in the room during disinfection,

- effectively destroys any genetic material, regardless of its size, resistance, or virulence,

- proven effectiveness in independent laboratory tests, - devices with relatively low noise level $(<50 \mathrm{db})$ are available.

Disadvantages:

- some of the devices work at volumes above $60 \mathrm{db}$,

- does not disinfect surfaces.

\section{CONCLUSIONS}

The market of medical systems for air and surface disinfection offers many devices that increase the standard of dental office sanitation. It should be noted that dental offices meet many high standards of cleanliness required by Polish Sanitary-Epidemiological Station. However, from the beginning of the $21^{\text {st }}$ century, every once in a while, the whole world is at higher risk of epidemic infection associated with the emergence of unknown viruses (SARS-CoV-1, MERS-CoV, H1N1, SARS-CoV-2). Therefore, it seems reasonable for dental clinics to be prepared in an optimal way for new threats. Existing disinfectants used in dental offices and methods of protection for medical staff provide a good standard of protection. Though, in a situation of increased risk of emergence of a new disease of viral origin, it may be essential to use currently available devices to ensure the purity of air and surfaces in dental offices. The study presented many devices and disinfectants that can be used in dental clinics, along with their pros and cons. Considering the advantages and disadvantages of devices described in this paper, the highest level of air disinfection is provided by plasma devices that work without any additional filters, which must be replaced. In turn, fumigators that use hydrogen peroxide for spraying provide the highest bactericidal, virucidal, and fungicidal effects on surfaces in the dental office (walls, medical devices, cabinets, countertops, etc.), with minimal side 
effects and short time needed to re-enter the office after disinfection. It should be remembered that the fumigators require hydrogen peroxide plasma or chemically stabilized hydrogen peroxide to operate with high efficiency at low solution percentage.

\section{CONFLICT OF INTEREST}

The authors declare no potential conflicts of interest with respect to the research, authorship, and/or publication of this article.

\section{References}

1. Gillespie JL, Arnold KE, Noble-Wang J, et al. Outbreak of Pseudomonas aeruginosa infections after transrectal ultrasound-guided prostate biopsy. Urology 2007; 69: 912-914.

2. Dominiak M, Różyło-Kalinowska I, Gedrange T, et al. COVID-19 and professional dental practice. The Polish Dental Association Working Group recommendations for procedures in dental office during an increased epidemiological risk. J Stomatol 2020; 73: 1-10

3. Ramanathan K, Antognini D, Combes A, et al. Transmission of SARS and MERS coronaviruses and influenza virus in healthcare settings: the possible role of dry surface contamination. J Hosp Infect 2020; 92: 235-250.

4. Meng L, Hua F, Bian Z. Coronavirus Disease 2019 (COVID-19): emerging and future challenges for dental and oral medicine. J Dent Res 2020; 99: 481-487.

5. Harrel SK, Molinari J. Aerosols and splatter in dentistry: a brief review of the literature and infection control implications. J Am Dent Assoc 2004; 135: 429-437.

6. Rutala WA, Weber DJ. New developments in reprocessing semicritical items. Am J Infect Control 2013; 41 (5 Suppl): S60-S66.

7. Rutala WA, Weber DJ. Disinfection of endoscopes: review of new chemical sterilants used for high-level disinfection. Infect Control Hosp Epidemiol 1999; 20: 69-76.

8. Juan MR, Herrin A, Concert C, et al. Guideline for use of high-level disinfectants and sterilants for reprocessing flexible gastrointestinal endoscopes. Gastroenterol Nurs 2015; 38: 70-80.

9. Lineback CB, Nkemngong CA, Wu ST, Li X, Teska PJ, Oliver HF. Hydrogen peroxide and sodium hypochlorite disinfectants are more effective against Staphylococcus aureus and Pseudomonas aeruginosa biofilms than quaternary ammonium compounds Antimicrob Resist Infect Control 2018; 7: 154. DOI: https://doi. org/10.1186/s13756-018-0447-5.

10. Alonso JM, Valdés M, Calleja AJ, Ribas J, Losada J. High frequency testing and modeling of silent discharge ozone generators. Ozone Sci Eng 2003; 25: 363-376.

11. From ozone generators to flat television screens: history and future potential of dielectric-barrier discharges. Pure and Applied Chemistry 1999; 71. Available at: https://www.degruyter.com/view/journals/pac/71/10/article-p1819.xml (Accessed: 24.05.2020).

12. US5130003A - method of powering corona discharge in ozone generators - Google Patents. Available at: https://patents.google. com/patent/US5130003A/en (Accessed: 24.05.2020).

13. Rogers JV, Choi YW. Inactivation of Francisella tularensis Schu S4 in a biological safety cabinet using hydrogen peroxide fumigation. Appl Biosaf 2008; 13: 15-20.

14. Meszaros JE, Antloga K, Justi C, Plesnicher C, McDonnell G. Area fumigation with hydrogen peroxide vapor. Appl Biosaf 2005; 10: 91-100

15. Magnavita N. A cluster of neurological signs and symptoms in soil fumigators. J Occup Health 2009; 51: 159-163.

16. US144962A - Improvement in fumigators - Google Patents. Available at: https://patents.google.com/patent/US144962A/en (Accessed: 24.05.2020).
17. Tanaka S, Abuku S, Seki Y, Imamiya S. Evaluation of methyl bromide exposure on the plant quarantine fumigators by environmental and biological monitoring. Ind Health 1991; 29: 11-21.

18. Workshop on Ultraviolet Disinfection Technologies \& Healthcare Associated Infections: Defining Standards and Metrology Needs | NIST. Available at: https://www.nist.gov/news-events/ events/2020/01/workshop-ultraviolet-disinfection-technologies-healthcare-associated (Accessed: 24.05.2020).

19. cie-releases-two-key-publications-uv-disinfection | CIE. Available at: http://cie.co.at/news/cie-releases-two-key-publicationsuv-disinfection (Accessed: 24.05.2020).

20. HEPA and ULPA Filters - ProQuest. Available at: https://search proquest.com/openview/955ada5d217bd22cf9a31441253b38ba/1?pq-origsite $=$ gscholar\&cbl=29232 (Accessed: 24.05 .2020 ).

21. Schroth T. New HEPA/ULPA filters for clean-room technology. Filtr Sep 1996; 33: 245-250.

22. US5582632A - Corona-assisted electrostatic filtration apparatus and method - Google Patents. Available at: https://patents.google. com/patent/US5582632A/en (Accessed: 24.05.2020).

23. US6482252B1 - Vacuum cleaner utilizing electrostatic filtration and electrostatic precipitator for use therein - Google Patents. Available at: https://patents.google.com/patent/US6482252B1/en (Accessed: 24.05.2020).

24. Grabarczyk Z. Effectiveness of indoor air cleaning with corona ionizers. J. Electrostat 2001; 51-52: 278-283.

25. Grinshpun S, Mainelis G. Evaluation of ionic air purifiers for reducing aerosol exposure in confined indoor spaces. 2005.

26. Green CF, Scarpino PV. The use of ultraviolet germicidal irradiation (UVGI) in disinfection of airborne bacteria. Environ Eng Policy 2001; 3: 101-107.

27. Kowalski WJ. Design and Optimization of UVGI Air Disinfection Systems; 2001.

28. UVGI design basics for air and surface disinfection - Penn State Available at: https://pennstate.pure.elsevier.com/en/publications/ uvgi-design-basics-for-air-and-surface-disinfection (Accessed: 24.05.2020).

29. Effective UVGI system design through improved modeling - ProQuest. Available at: https://search.proquest.com/openview/ 9193ad710b77f41e531bd7a59988f66e/1?pq-origsite=gscholar\&cbl=34619 (Accessed: 24.05.2020).

30. Zhao J, Yang X. Photocatalytic oxidation for indoor air purification: a literature review. Build Environ 2003; 38: 645-654.

31. Zuraimi MS, Vuotari M, Nilsson G, Magee R, Kemery B, Alliston C. Impact of dust loading on long term portable air cleaner performance. Build Environ 2017; 112: 261-269.

32. Reactive bed plasma air purification; 1990

33. Nishikawa K, Nojima H. Air purification effect of positively and negatively charged ions generated by discharge plasma at atmospheric pressure. Japanese J Appl Phys 2001; 40 (Part 2, No. 8A): L835.

34. Nishikawa K, Cook M. Air purification technology by means of cluster ions generated by plasma discharge at atmospheric pressure. In: Bioengineering in Cell and Tissue Research. Berlin Heidelberg: Springer; 2008. 